Пришляк Галина Ярославівна кандидат юридичних наук, доцент, доцент кафедри права, Львівський інститут ПрАТ «ВНЗ «МАУП», вул. Г. Мазепи, 29, м. Львів, 79059, тел.: (032) 294-00-81, e-mail: kga82@ukr.net, https://orcid.org/0000-0002-7056-4210

\title{
ФОРМИ ЗДІЙСНЕННЯ КОНТРОЛЮ НАРОДУ ЯК ВАЖЛИВІ ПЕРЕДУМОВИ ГАРАНТІЙ РЕАЛІЗАЦЇ̈ ЕКОЛОГІЧНИХ ПРАВ В УКРАЇНI
}

Анотація. Реформа конституційного спрямування, яка почалася в Україні ще в середині 90-х рр., поки що важко назвати завершеною. Проте, необхідно підкреслити, що апогей реформаторських зусиль припав на червень 1996 р., коли був прийнятий надважливий документ для країни - чинну Конституцію України. За двадцять п'ять років дії Основного Закону теперішнім суспільством він сприймається вже не як тільки продукт та засіб державної влади, а як справжній офіційний вираз інтересів громадянського суспільства та консенсуальна платформа для його існування. Крім того, його правовий акцент змістився 3 вузькокласових до громадянських та загальнолюдських інтересів та цінностей. Першочергового значення набули конституційний статус громадянина та закріплення його широких прав та свобод, а також й обов'язків. Важливе значення у захисті цього правового статусу індивіду у нашій державі мають міжнародні пакти й угоди, підписані та ратифіковані Україною. Українські законотворці, визнавши концепцію поділу, врівноваження різних гілок державної влади та їх взаємної співпраці, все ще не зуміли, на наш погляд, знайти іiі оптимальне поєднання 3 принципами народовладдя, оскільки народ, який $\epsilon$ суб'єктом влади, реалізує їі у різних формах, в тому числі і за допомогою контролю, який є важливою передумовою гарантій реалізації прав та свобод, в тому числі й екологічних. Все більш очевидною стає необхідність розроблення відповідного правового механізму реалізації неруйнівного такого контролю, який неможна уявити без використання комплексу засобів різного характеру (юридичних, організаційних, інституціональних, матеріально-фінансових, соціально-психологічних тощо). Звичайно, що такий процес не буде короткочасним, оскільки характеризує певні цикли та фази свого переходу. Зроблено висновки про те, що необхідно офіційно визнати контроль народу, який $\epsilon$ важливою передумовою гарантій реалізації прав та свобод, в тому числі й 
екологічних, реалізовувати його не хаотично, а цілеспрямовано та організовано, в рамках політико-правової системи через механізм державного будівництва. Оскільки він $є$ тим стабілізуючим елементом, наявність та функціонування якого не лише забезпечує зворотний зв'язок і вплив пересічних громадян на владні структури, а й слугує найважливішою умовою реалізації основної засади народовладдя.

Ключові слова: контроль народу, екологічні права і свободи громадян, гарантії реалізації прав, контроль.

Pryshliak Halyna Yaroslavivna Candidate of Law, Associate Professor, Associate Professor of the Department of Law, Lviv Institute of PJSC MAUP University, G. Mazepy St., 29, Lviv, 79059, tel.: (032) 294-00-81, e-mail: kga82@ukr.net, https://orcid.org/0000-0002-7056-4210

\section{FORMS OF PEOPLE CONTROL AS IMPORTANT PREREQUISITES FOR GUARANTEES OF EXERCISE OF ENVIRONMENTAL RIGHTS IN UKRAINE}

Abstract. The reform of the constitutional direction, which began in Ukraine in the mid-1990s, is still difficult to call complete. However, it should be emphasized that the apogee of the reform efforts came in June 1996, when an important document for the country was adopted - the current Constitution of Ukraine. In the twenty-five years of the Basic Law, it has been perceived by today's society not only as a product and a means of state power, but as a real official expression of the interests of civil society and a consensual platform for its existence. In addition, its legal emphasis has shifted from narrow-class to civic and universal interests and values. The constitutional status of the citizen and the consolidation of his broad rights and freedoms, as well as responsibilities, have become paramount. International covenants and agreements signed and ratified by Ukraine are important in protecting this legal status of an individual in our country. Ukrainian lawmakers, recognizing the concept of division, balancing the various branches of government and their mutual cooperation, still failed, in our opinion, to find its optimal combination with the principles of democracy, as the people who are the subject of power, implement it in various forms, including through control, which is an important prerequisite for guarantees of realization of rights and freedoms, including environmental ones. The need to develop an appropriate legal mechanism for the implementation of such non-destructive control, which cannot be imagined without the use of a set of tools of different nature (legal, organizational, institutional, financial, financial, socio-psychological, etc.) is becoming increasingly apparent. Of course, such a process will not be short-lived, as it characterizes certain 
cycles and phases of its transition. It is concluded that it is necessary to officially recognize the control of the people, which is an important prerequisite for guarantees of rights and freedoms, including environmental, to implement it not chaotically, but purposefully and organized, within the political and legal system through the mechanism of state building. Because it is the stabilizing element, the presence and functioning of which not only provides feedback and influence of ordinary citizens on the power structures, but also serves as the most important condition for the implementation of the basic principle of democracy.

Keywords: control of the people, environmental rights and freedoms of citizens, guarantees of realization of rights, control.

Постановка проблем. Участь народу у здійсненні влади та контроль за діяльністю як держави загалом, так і іï органів, може бути представлений у різноманітних формах. Така різнобічність контролю обумовлена широким спектром функцій, які виконує держава та іï органи, їх складністю і просторовочасовою протяжністю. Сама форма держави з іiі специфічними особливостями, що реалізується через форму правління, державний устрій і державний режим багато у чому, якщо не в головному, позначається на характері та змісті правового контролю народу за органами державної влади та управління.

Тому, побудова демократичної, правової держави неможлива без належного контролю народу за діями органів держави, адже це показник гарантій реалізації прав та свобод, зокрема екологічних, в Україні, а також вказує на фактичний стан діяльності держави, іiі структури та конкретних дій державних службовців, їх відповідність чи не відповідність потребам соціально-економічного розвитку суспільства. Бо саме контроль народу покликаний діяти у відповідності 3 державним будівництвом та виконувати поставлені перед ним завдання.

Аналіз останніх досліджень і публікацій. Проблеми контролю народу завжди були актуальними й залишилися такими донині. Це підтверджується значною кількістю наукових доробок вітчизняних авторів, серед яких В. Зуєв, О. Мурашин, М. Малишко, В. Цвєтков та ін. Науковим розробкам у досліджуваній галузі бракує погляду на визначення форм контролю народу, які $\epsilon$ важливою передумовою гарантій реалізації екологічних прав в Україні. Відсутність наукового обгрунтування в даній сфері призводить до того, що більшість механізмів, які функціонують у межах системи народного контролю, потребують удосконалення, а особливо, визначення форм такого контролю.

Мета статті - визначення форм контролю народу як важливої передумови гарантій реалізації екологічних прав в Україні.

Виклад основного матеріалу. Важливість контролю народу у різних сферах державної та суспільної діяльності не викликає сумнівів, а його рівень відповідає 
показнику розвитку демократії, інститутам громадянського суспільства, їх впливу на органи державної влади. Контроль з боку суспільства покликаний підвищити відповідальність держави перед своїми громадянами за свої рішення та за досягнення взятих на себе державою зобов'язань. В такому випадку, контроль стає як невід’ємна частина розвитку суспільства. Значення його проявляється в аналізі та перевірці діяльності учасників суспільних відносин відповідно до встановлених приписів. Розглядаючи демократичне суспільство в системі державного управління, В.В. Цвєтков зазначав, що це таке суспільство, яке здатне контролювати процес державного управління та справляти на нього правомірний та раціонально обгрунтований вплив [1, с. 163].

В. Зуєв, вивчаючи різновиди вчень про демократію, виділяє ті 3 них, де народ розглядається як «активний учасник і контролер роботи власних органів...» [2, с. 95]. Це перегукується 3 поглядом Г.Х. Шахназарова на демократичний контроль як головну форму участі народу в управлінні. В його трактуванні це зовсім не означає участі в управлінні всіх громадян відразу або завжди усіх. «Важливо лише, - писав Г.Х. Шахназаров, - щоб: а) кожна основна ланка управлінського процесу була підконтрольна народові; б) кожний громадянин мав свій вихід (або залучався) до участі у тій або іншій формі контролю» [3, с. 177].

Для глибшого розуміння сутності цього поняття важливо врахувати семантику слова «контроль». Український тлумачний словник подає таке його тлумачення: а) перевірка, звіт діяльності кого- чи чого-небудь, нагляд за кимось чи чимось; б) заклад, який здійснює нагляд за кимось або чимось, чи перевіряє когось [4, с. 318]. Таке ж трактування поняття «контроль» знаходимо і в словнику іншомовних слів [5].

В англійсько-українському словнику термінів i понять 3 державного управління термін «контроль» трактується як облік, спостереження за будь-чим, перевірка діяльності будь-якої іншої організації або відповідальної особи, звітність, аналіз результатів їх діяльності й виконання стратегічних планів, вжиття заходів щодо корегування таких планів для досягнення необхідних результатів, а також зазначено, що контроль - це будь-яка перевірка відповідності конкретного об'єкта встановленим обмеженням, засоби впливу організації на досягнення необхідних результатів i контролю відповідності кількості і якості таких результатів організаційній специфіці [6, с. 80]. Слід зазначити, що це тлумачення терміну «контроль» найбільше відповідає юридичному змісту контролю як форми безпосередньої участі народу у здійсненні контролю за діяльністю органів державної влади.

Тому можна визначити, що контроль народу є одним із видів соціального контролю, який є дуже важливим для формування правової свідомості громадян, налагодження взаємозв’язків між народом та органами державної влади, а також, 
важливою гарантією реалізації прав та свобод, особливо екологічних, які на сьогоднішній день є не зовсім досліджені.

Характерними рисами такого контролю є здійснення громадянами перевірки раціональності, економності, об'єктивної професійної обгрунтованості рішень органів державної влади щодо екологічних питань, які виходять за межі правомірності, доцільності тих чи інших процесів в управлінні державними справами, а також контроль народу дозволяє одержати значний обсяг інформації, що допомагає йому брати активну участь у здійсненні державної влади в екологічній сфері.

Крім того, слід виділяти і форми контролю, які є елементами, що погоджено функціонують і в певний спосіб поєднуються, утворюючи механізм здійснення народом контролю.

Враховуючи широкий спектр функцій, які виконує держава та іï органи, їх складність, участь народу у здійсненні влади та контроль за діяльністю як держави загалом, так і іï органів може бути представлений у численних правових формах. До таких правових форм контролю народу належать: всенародні голосування (референдуми); громадські ініціативи; збори та зібрання громадян за місцем їх проживання; реалізація громадянами усього комплексу прав і свобод.

Аналізуючи ступінь реалізації правових форм контролю народу в Україні, хочемо відзначити, що чинні правові норми не зовсім відповідають зазначеним питанням. Тому маємо деякі пропозиції щодо удосконалення теперішнього законодавства у питаннях контролю народу.

Так, слід зазначити, що перелік прав та свобод в чинному законодавстві України може та повинен бути доповнений правом громадян та їх об'єднань на контроль у діяльності органів державної влади, який є важливою передумовою гарантій реалізації прав та свобод людини, особливо екологічних.

Крім того, важливою формою контролю народу $є$ всенародне голосування (референдум), яке є безпосереднім проявом волевиявлення громадян. Першим, хто охарактеризував референдум як форму демократичного контролю, був Ю. Гачек, котрий у своїй монографії присвятив висвітленню цього питання спеціальний розділ «Засоби контролю над законодавчою владою, зокрема референдум». У ньому автор обгрунтував положення, за яким у державах, де нема панування партій як у безпосередній демократії, доречно як дієвий спосіб народного контролю застосувати референдум, який є засобом залучення народу до участі в законотворчості без посередництва представників, тобто шляхом народного голосування, при якому сукупність усіх квотує постанови, прийняті законодавчим корпусом, або на вимогу певного числа громадян або установи [7, с. 89].

3 українських вчених цікаву позицію займає М.І. Малишко, який визначає поняття «референдум» як спосіб волевиявлення громадян шляхом голосування 3 
приводу прийняття законів та інших рішень або дорадчого опитування 3 важливих питань загальнодержавного та місцевого значення [8, с. 17]. Аналогічне розуміння цього поняття висловлено й іншими вітчизняними науковцями.

Натомість значно повніше та всебічніше охарактеризував сутність референдуму О. Мурашин. Учений вважав його важливим державно-правовим інститутом безпосередньої демократії, через який реалізується суверенітет народу шляхом голосування за законопроекти та питання, що мають принципове значення для держави загалом або для їі окремих адміністративно-територіальних одиниць [9, с. 24]. На відміну від цього, поняття «референдум», що міститься в Конституції України 1996 р., не дає чіткого уявлення про його суть, хоча в Основному Законі підкреслено, що він $є$ народним волевиявленням та формою безпосередньої демократії [10, ст. 69].

На початку цього року нарешті відбулося прийняття нормативного акту, що регулює такий вид контролю - Закон України «Про всеукраїнський референдум» від 26 січня 2021 року, в преамбулі якого зазначено основне його завдання визначення правових засад «здійснення народного волевиявлення через всеукраїнський референдум, його організацію та порядок проведення» [11].

Окремими контрольними повноваженнями наділені зібрання та збори громадян за місцем їх проживання, які застосовуються для проведення населенням всенародних i регіональних обговорень життєво важливих питань політики, економіки і права. Після проведення соціологічних досліджень 3 проблем участі громадськості в загальних зборах, зібраннях за місцем їх проживання у містах та районах всіх областей України показали доволі низьку соціальну активність громадян. До того ж існує загальноукраїнська тенденція зменшення рівня цієї активності з переходом від локального рівня до загальнонаціонального [12, с. 118119]. Проблема полягає в тому, що більшість громадян не усвідомлює свого реального впливу на діяльність органів державної влади та не вміє використовувати увесь спектр своїх прав та свобод.

У надто складному процесі зміцнення національної державності демократизм політичної влади не може бути гарантованим без зацікавленої участі та масової політичної активності громадян, що проявляється через різноманітні громадські ініціативи. Такий ефективний контроль народу за діяльністю органів державної влади доволі успішно реалізується в деяких країнах Заходу.

У здійсненні належного контролю народом, важливим є їх об’єднання. Так, у ст. 22 Закону України «Про громадські об’єднання» $є$ необхідність уточнення поняття «втручання», де йдеться про взаємини держави і об'єднань громадян, зазначено, що втручання державних органів та службових осіб у діяльність об’єднань громадян, так само як і втручання об'єднань громадян у діяльність 
державних органів, службових осіб та у діяльність інших об'єднань громадян, не допускається, крім випадків, передбачених Законом [13]. Відсутність у Законі трактування терміну «втручання», котрий може розумітися в кількох аспектах, призводить, на наш погляд, до певної колізії. Насправді ж в українській мові слово «втручання» (втручатися)

означає «самочинно займатися чиїмись справами,встрявати в чиї небудь стосунки тощо; вплутуватися, лізти, вмішуватися» [14, с. 394]. Звісно, втручання може бути різним. Тому, слід зазначити, що стосується втручання партій та громадських організацій у діяльність несудових органів державної влади і посадових осіб, то воно не тільки невідворотне, а й цілком допустиме у межах правового контролю громадян та їх об’єднань над державними органами. I його некоректно обмежувати переліком прав громадських об'єднань, зафіксованим в ст. 22 Закону України «Про громадські об’єднання» [13].

Висновки. Підсумовуючи вищевикладене, хочемо визначити такі основні напрями здійснення контролю народу в Україні: визнання такого комплексного правового інституту, як інститут контролю народу; залучення громадян (через партії та інші інститути громадянського суспільства) до процесів державного управління на засадах народовладдя; запровадження реальних механізмів дієвого діалогу влади з населенням; створення ефективних важелів для реалізації чинних та прийняття нових законодавчих актів, які б були гарантіями реалізації прав i свобод людини, особливо екологічних. I крім того, очевидно, що усі суспільні формування, етнічні та соціальні спільноти, громадяни та суспільство загалом можуть і повинні глибоко усвідомити та засвоїти правові приписи, визнати нагальну потребу керуватися ними, захищати їх та забезпечувати постійний контроль над їх дотриманням усіма державними структурами.

\section{Лimepamypa:}

1. Цвєтков В.В. Державне управління і політика: монографія. К. : Абрис, 2006. 325 с.

2. Зуев В.Й. «Власть» в системе политологических категорій. Государство и право. 1992. № 5. С. 90-97.

3. Шахназаров Г.Х. Социалистическая демократия. Некоторые вопросы теории. 2-е изд., доп. М. : Политиздат, 1974. 336 с.

4. Новий тлумачний словник української мови : у 4-х т. / уклад. В.В.Яременко, О.М. Сліпушко. К. : Аконіт, 1999. Т. 2. 910 с.

5. Словник іншомовних слів / за ред. О.С. Мельничука. URL: https://ev.vue.gov.ua/wpcontent/uploads/2018/04/\%D0\%9C\%D0\%B5\%D0\%BB\%D1\%8C\%D0\%BD\%D0\%B8\%D1\%87\%D1 \%83\%D0\%BA-\%D0\%9E.-\%D1\%80\%D0\%B5\%D0\%B4.-\%D0\%A1\%D0\%BB\%D0\%BE\%D0\%B2\% D0\%BD\%D0\%B8\%D0\%BA\%D0\%BD\%D1\%88\%D0\%BE\%D0\%BC\%D0\%BE\%D0\%B2\%D0\%BD $\% \mathrm{D} 0 \% \mathrm{~B} 8 \% \mathrm{D} 1 \% 85-\% \mathrm{D} 1 \% 81 \% \mathrm{D} 0 \% \mathrm{BBi} \% \mathrm{D} 0 \% \mathrm{~B} 2 . p d f$ (дата звернення 19.08.2021 р.)

6. Англійсько - український словник термінів і понять 3 державного управління. К. : Основи, 1996. 128c. : Бібліограф. С. 126 - 127. 
7. Общее государственное право на основе сравнительного правоведения / под ред. и с предисл. М.А. Рейснера, прив. Рига : Наука и жизнь, 1913. Ч. 2 : Право современной демократии. $607 \mathrm{c}$.

8. Малишко M.І. Коституційно-правові основи виборів і референдумів як форм прямого народовладдя. К., 1996. 30 с.

9. Мурашин О.Г. Акти прямого народовладдя у правовій системі. К. : Знання, 1999. 185 с.

10. Конституція України від 28 червня 1996 р. Відомості Верховної Ради України. 1996. № 31. Ст. 141.

11. Про всеукраїнський референдум: Закон України від 26 січня 2021 року. Офіційний вісник України. 2021. № 31. С. 11. Ст. 1762

12. Бойко Н. Социальный контроль и демократизация общества. К. : Институт социологии НАНУ, 2007. 272 с.

13. Про громадські об'єднання: Закон України від 22 березня 2012 р. Відомості Верховної Ради України. 2013. № 1. Ст. 1.

14. Новий тлумачний словник української мови : у 3-х т. / уклад. В.Яременко, О.Сліпушко. 2-е вид., випр. К. : Аконіт, 2001. Т. 1. 926 с.

\section{References:}

1. Cvjetkov V.V. (2006) Derzhavne upravlinnja i polityka [Public administration and politics]. Kyiv: Abrys [in Ukrainian].

2. Zuev V.J. (1992). «Vlastj» V systeme polytologhycheskykh kateghorij ["Power" in the system of political science categories]. Ghosudarstvo y pravo, 5, 90-97 [in Ukrainian].

3. Shakhnazarov Gh.Kh. (1974). Socyalystycheskaja demokratyja. Nekotorbe voprosы teoryy [Socialist Democracy. Some questions of theory]. Moskov : Polytyzdat [in Russian].

4. Jaremenko V.V., Slipushko O.M. (1999). Novyj tlumachnyj slovnyk ukrajinsjkoji movy [New explanatory dictionary of the Ukrainian language]. (Vols. 1-4). Kyiv : Akonit [in Ukrainian].

5. Meljnychuka O.S. (1974). Slovnyk inshomovnykh sliv [Dictionary of foreign words]. Retrieved from https://ev.vue.gov.ua/wp-content/uploads/2018/04/\%D0\%9C\%D0\%B5\%D0\%BB\% D1\%8C\%D0\%BD\%D0\%B8\%D1\%87\%D1\%83\%D0\%BA-\%D0\%9E.\%D1\%80\%D0\%B5\%D0\%B4.\%D0\%A1\%D0\%BB\%D0\%BE\%D0\%B2\%D0\%BD\%D0\%B8\%D0\%BA-i\%D0\%BD\% D1\%88\%D0\% BE\%D0\%BC\%D0\%BE\%D0\%B2\%D0\%BD\%D0\%B8\%D1\%85-\%D1\%81\%D0\%BBi\%D0\%B2.pdf [in Ukrainian]

6. English - Ukrainian dictionary of terms and concepts of public administration (1996). Kyiv: Osnovy [in Ukrainian].

7. Rejsnera M.A. (1913). Obshhee ghosudarstvennoe pravo na osnove sravnyteljnogho pravovedenyja [General state law on the basis of comparative jurisprudence]. Rygha : Nauka y zhyznj [in Latviia].

8. Malyshko M.I. (1996). Kostytucijno-pravovi osnovy vyboriv i referendumiv jak form prjamogho narodovladdja [Constitutional and legal bases of elections and referendums as forms of direct democracy]. Kyiv [in Ukrainian].

9. Murashyn O.Gh. (1999). Akty prjamogho narodovladdja u pravovij systemi [Acts of direct democracy in the legal system]. Kyiv : Znannja [in Ukrainian]

10. Konstytucija Ukrajiny [The Constitution of Ukraine]. (1996, June 28). Vidomosti Verkhovnoi Rady Ukrainy - Bulletin of Verkhovna Rada of Ukraine. Kyiv: Parlam. vyd-vo [in Ukrainian].

11. Zakon Ukrajiny Pro vseukrajinsjkyj referendum: pryiniatyi 26 sichnja 2021 roku. [Law of Ukraine on the All-Ukrainian Referendum from January 26 2021, № 1135-IX]. (2021, April10). 
Holos Ukrainy - Voice of Ukraine, 67 [in Ukrainian].

12. Bojko N. (2007). Socyaljnыj kontrolj y demokratyzacyja obshhestva [Social control and democratization of society]. Kyev : Ynstytut socyologhyy NANU [in Ukrainian].

13. Zakon Ukrajiny Pro ghromadsjki ob'jednannja: pryiniatyi 22 bereznja 2012 roku. [Law of Ukraine On public associations from March 222012 № 4572-VI]. Vidomosti Verkhovnoi Rady Ukrainy - Bulletin of Verkhovna Rada of Ukraine. Kyiv: Parlam. vyd-vo [in Ukrainian].

14. Jaremenko V., Slipushko O. (2001). Novyj tlumachnyj slovnyk ukrajinsjkoji movy [New explanatory dictionary of the Ukrainian language]. (Vols. 1-3). Kyiv : Akonit [in Ukrainian]. 